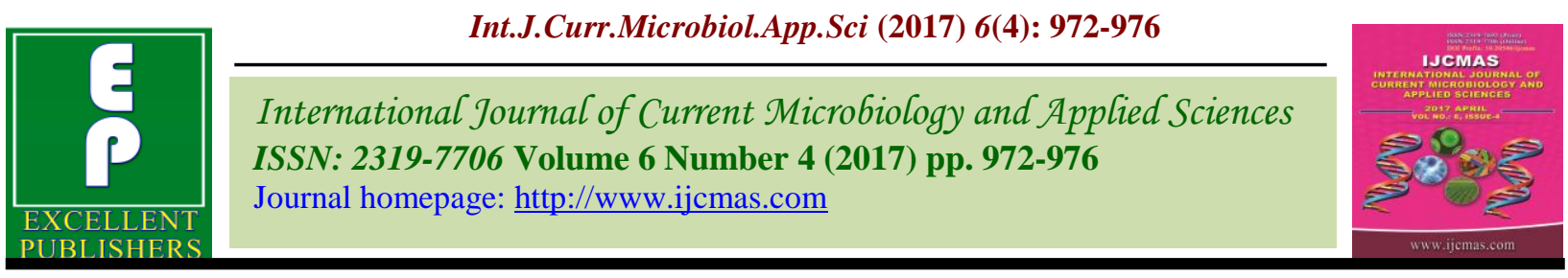

Original Research Article

https://doi.org/10.20546/ijcmas.2017.604.122

\title{
Response of Chilli (Capsicum annuum L.) to Different Sources and Combination of Nitrogen
}

\author{
Anupam Pariari and Suddhasuchi Das* \\ Department of Spices and Plantation Crops, Faculty of Horticulture, Bidhan Chandra Krishi \\ Viswavidyalaya, Mohanpur, Nadia, West Bengal-741252, India \\ *Corresponding author
}

A B S T R A C T

Ke y w o r d s
Chilli, Flowering,
Growth, Nitrogen,
Quality and yield.
Article Info
Accepted:
12 March 2017
Available Online:
10 April 2017

To identify the best source of nitrogen among organic and inorganic sources and their combinations for better growth, flowering behaviour and fruit yield of chilli cv. Bulet, an experiment was conducted in Gangetic Alluvial plain of West Bengal. Six organic manures in different combinations were applied along with Urea at three levels $(25 \%, 50 \%$, and 75$)$. Result showed that plant height and number of branches per plant was found maximum with a combination of vermicompost and urea at $50 \%$. Flowering was delayed with increase in inorganic nitrogen level $(25,50$ and $75 \%)$ in the growing media. The yield attributes including fruit yield was found maximum also with nitrogen received from vermicompost and urea at 50\% level. However, all the treatments showed the enhanced results over control (with no nitrogen). The qualitative aspects were increased with the application of neem cake compared to other inorganic sources.

\section{Introduction}

Among the spice crops of India Chilli (Capsicum annuum L.), a member of Solanaceae family is an important one. Being introduced by Portuguese in 17th century, now the crop is grown all over India, especially in Andhra Pradesh, Karnataka, Tamil Nadu and Maharashtra, account for 3/4 of the total area besides Madhya Pradesh, West Bengal, Punjab, Bihar and Rajasthan (Khan and Pariari, 2012), Dried fruits are used to make universal curry powder and curry paste. The fruit of chilli contains carbohydrates, vitamin A and vitamin C. Fresh green and ripe chillies are used to make all kinds of pickles, different sauces and paste. The red colour, capsanthin is used in high quality cosmetic preparations like lipstick. The essential oil, oleoresin is used in the food and beverage industries. The pungency is due to an active principle "Capsaicin" an alkaloid present in pericarp and placenta, which are a digestive stimulant and an important ingredient of daily diet and a cure for many rheumatic problems (Chandini Raj et al., 2016). Nitrogen ( $\mathrm{N}$ ) is a major constituent of several of the most important substances which occur in plants. It is of outstanding importance among the essential elements in the $\mathrm{N}$ compounds comprises from 40 to $50 \%$ of the dry matter of the protoplasm, the living substance of plant cells (Togun et al., 2003). Nitrogen is known to promote production, partitioning and accumulation of dry matter in crop plant 
(Akanbi et al., 2007). Tumbare et al., (2004) reported that $\mathrm{N}$-fertilizers increased fruit weight, yield and fruit number of chilli peppers. Improved nitrogen management can be achieved by matching nitrogen supply with crop need and selecting appropriate nitrogen level to minimize nitrate nitrogen accumulation in soil at times, when the leaching potential is high (Papendick, 1987). However, information regarding the response of chilli to different sources and combination of nitrogen in alluvial plains of West Bengal is meager. Hence, the present study was conducted to determine the effect of different nitrogen source on growth, reproductive behaviour and quality of chilli.

\section{Materials and Methods}

\section{Experimental site}

The present investigation was carried out at Horticultural Research Station, Mondouri, Faculty of Horticulture, Bidhan Chandra Krishi Viswavidyalaya, Nadia, and West Bengal in consecutive two seasons during 2013-14 and 2014-15 in chilli cv. Bulet in Gangetic Alluvial Plains with soil pH 6.7.

\section{Experimental details}

The plants were manured with six organic manures like cowdung, neem cake, poultry manure, vermicompost, phosphocompost and mustard cake along with inorganic source of nitrogen viz. urea. Full dose of organic manure including recommended dose of $\mathrm{P}$ (Single Super Phosphate) and K (Muriate of Potash) and 50\% dose of urea was applied as basal. Rest amount was applied after one month of transplanting.

The seedlings were planted in the plots measuring $4.5 \mathrm{~m} \times 1.5 \mathrm{~m}$ with spacing of 60 $\mathrm{cm}$ (Row to Row) x $45 \mathrm{~cm}$ (Plant to Plant) following RBD with 19 treatments (Table 1) and 3 replications. The plants in the control plot were grown only with $\mathrm{P}$ and $\mathrm{K}$, but without any N. Matured green fruits were harvested from the plants in phases up to the drying of the plants. Observations were recorded on different growth, flowering behaviour and quality parameters and analyzed statistically (Gomez and Gomez, 1984). Capsaicin and Ascorbic acid content of chilli were estimated following Standard biochemical method (Sadasivam and Manickam, 1996).

\section{Results and Discussion}

\section{Plant height (cm)}

The average plant height of chilli $(69.56 \mathrm{~cm})$ was found maximum with $50 \% \mathrm{~N}$ from Vermicompost $+50 \% \mathrm{~N}$ from Urea. It was seen that plant height increased with the increase in the level of inorganic nitrogen (25 to $75 \%$ ) and with reduced level of organic manure. Whereas, reverse effect was found with neem cake, poultry manure, vermicompost and phosphocompost. The minimum $(61.24 \mathrm{~cm})$ plant height was recorded in treatment $\mathrm{T}_{19}$ (control plot). Similar findings were also reported by Chandrappa et al., (2007) in chilli. It shows that the effect of nitrogenous fertilizers has similar effect on plant height of chilli, but varies with the changes in dose of nitrogen.

\section{Number of branches per plant}

The average number of branches per plant was found maximum (16.01) under the treatment with $50 \% \mathrm{~N}$ from vermicompost + $50 \% \mathrm{~N}$ from Urea $\left(\mathrm{T}_{11}\right)$ over other treatments. Whereas, number of branches per plant (12.83) was found the least, when plant was grown with only $\mathrm{P}$ and $\mathrm{K}$ (Control), Yadav and Vijayakumari (2004) found maximum chlorophyll content in chilli plant with $\mathrm{VC}$ as compared to other organic manures used. 
Table.1 Effect of source and combination of nitrogen on growth, growth attribute and fruit yield of chilli (pooled data of two years)

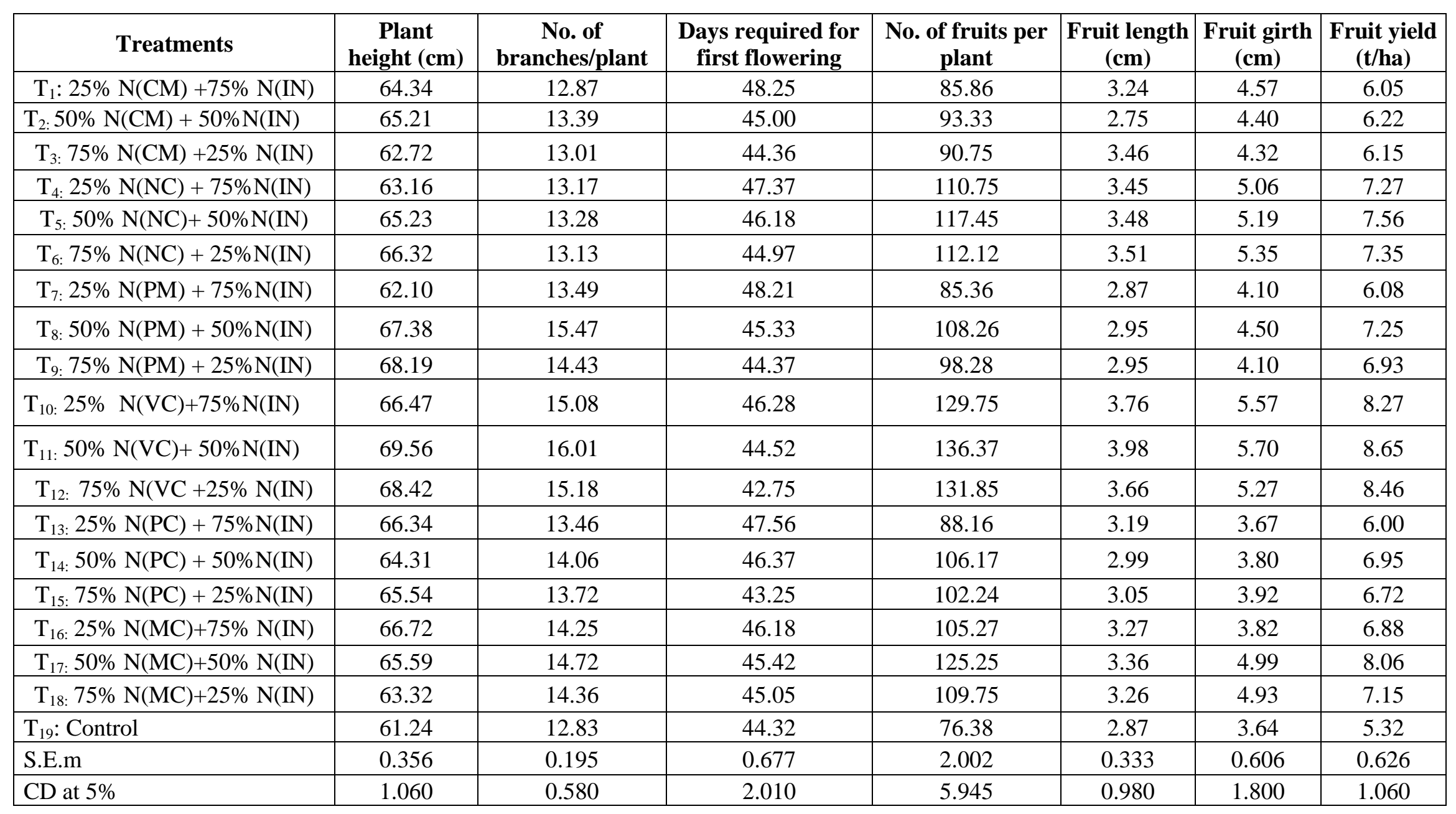




\section{Days required to first flowering}

Application of $\mathrm{N} @ 75 \%$ through vermicompost and rest from urea induced advanced flowering in plants $\left(\mathrm{T}_{12}\right)$ as compared to all other treatments. On the other hand, flowering

\section{Length of fruit (cm)}

The data of the length of fruit presented in table 1 which shows that $50 \% \mathrm{~N}$ from vermicompost $+50 \% \mathrm{~N}$ from urea $\left(\mathrm{T}_{11}\right)$ produced longer fruit (3.98), which was statistically at par with $\mathrm{T}_{10}(25 \% \mathrm{~N}$ from vermicompost $+75 \% \mathrm{~N})$. Whereas, the minimum $(2.87 \mathrm{~cm})$ fruit length was obtained from $\mathrm{T}_{19}$ (control).

\section{Fruit girth (cm)}

The effect of organic manure with different level of inorganic fertilizer also influenced the fruit girth to a considerable extent. Among the different treatments the maximum $(5.70 \mathrm{~cm})$ fruit diameter was recorded in $\mathrm{T}_{11}(50 \% \mathrm{~N}$ from vermicompost $+50 \% \mathrm{~N}$ from urea). The minimum was observed in $(3.64 \mathrm{~cm})$ Control $\operatorname{plot}\left(\mathrm{T}_{19}\right)$.

\section{Fruit yield (t/ ha)}

The fruit yield per hector showed highly significant variation. It is evident from the data that the treatment $\mathrm{T}_{11}(50 \% \mathrm{~N}$ from vermicompost $+50 \% \mathrm{~N}$ from urea) significantly produced the highest yield per hectare compared to other treatments.

Various organic manures when mixed with growing media showed their significant role to boost yield of chilli like other parameters. When soil was enriched with vermicompost and urea, $50 \%$ more yield was found, whereas, other organic manures like cow dung manure, poultry manure, neem cake, phosphocompost and mustard cake improved yield to some extent, but not up to the mark of the above mention treatment. The maximum (8.65t/ha) fruit yield was obtained when plants were treated with $50 \% \mathrm{~N}$ from vermicompost $+50 \% \mathrm{~N}$ from urea $\left(\mathrm{T}_{11}\right)$. Chopra et al., (2005) found the superior yield of chilli genotypes with organic and inorganic nutrient combination. Usha Rani et al., (2002) observed that the availability of phosphorus contents increased up to $200 \%$ in the soil during cultivation of chilli, when NPK + FYM @ 10 tons/ha is used in the soil followed by vermicompost@2.5 tonnes/ha with the same level of inorganic fertilizer.

\section{Capsaicin and Ascorbic Acid content of Fruits}

Fruit samples were collected when the fruits started ripening and were analyzed to find out the capsaicin and ascorbic acid status of the fruits. The highest content of capsaicin and ascorbic acid in fruit were recorded when plants were treated with $25 \% \mathrm{~N}$ from Neem cake and $75 \% \mathrm{~N}$ from urea (T6) followed by $50 \% \mathrm{~N}$ from Cow dung manure $+50 \% \mathrm{~N}$ taken from urea (T5). These results are in agreement with the results of Grubben and ElTahir (2004) who confirmed that vitamin C content of hot paper exceeds the value in tomato such that one serving of red pepper fruits contains nearly twice the daily requirement.

In conclusion, from the result it may be concluded that application of organic manure specially vermicompost may replace up to $50 \%$ of inorganic nitrogen fertilizers requirement of the crop to produce the maximum fruit yield. Qualitative characters, especially antioxidants like ascorbic acid and capsaicin content in fruit may be improved to a maximum extent with addition of neem cake in soil @75\% of total $\mathrm{N}$ requirement of the crop. 


\section{References}

Akanbi, W.B., Togun, A.O., Olaniran, O.A., Akinfasoye, J.O. and Tairu, F.M. 2007. Physico-chemical properties of Eggplant (Solanum meloongena L.) fruit in response to nitrogen fertilizer and fruit size. Agri. J., 2: 140-148.

Chandini raj, A., Holebasappa, K., Hore, J. K. and Chattopadyay, N. 2016. Growth and yield of chilli (capsicum annuum 1.) as influenced by different growth regulators. The Bioscan, 11(1): 385388.

Chandrappa, H., Venkatesh, J., Sharanappa, J. and Prasad, R. 2007. Influence of Azotobacter, Azospirillum and nitrogen on growth, yield and quality of Chilli. Proc. Nat. Sem. Production, Development, Quality and Export of seed Spices, NRCSS, Ajmer, pp. 278283.

Chopra, S., Gupta, A.K., Samnotra, R.K. and Bhushan, A. 2005. Performance of chilli (Capsicum annuum L.) genotypes under sub-tropical conditions of Jammu. Environ. Ecol., 23: 323-324.

Gomez, K.A. and Gomez, A.A. 1984. Statistical Procedures in Agricultural Research, Wiley, New York, Chichester, 2nd edition, pp. 680.

Khan, S. and Pariari, A. 2012. Effect of nfixing biofertilizers on growth, yield and quality of chilli (Capsicum annuum 1.). The Bioscan, 7(3): 481-482.
Papendick, R.I., Elliot, L.F. and Power, J.F. 1987. Alternative production systems to reduce nitrates in ground water. Am. J. Alternative Agr., 11: 19-24

Sadasivam, S. and Manickam, A. 1996. Biochemical Methods (2nd edn) New Age International Publisher, New Delhi, pp. 187-188.

Singh, P. and Kumar, A. 1999. Genetic Variability, heritability and genetic advances on chilli (Capsicum annuиm L.). Indian J. Agri. Sci., 77: 459-461.

Togun, A.O., Akanbi, W.B. and Dris, R. 2003. Influence of compost and nitrogen fertilizer on growth, nutrient uptake and fruit yield of tomato (Lycopersicum esculentum). J. Crop Res., 98: 40-56.

Tumbare, A.D. and Niikam, D.R. 2004. Effect of planting and fertigation on growth and yield of green chili (Capsicum annuum). Indian J. Agri. Sci., 74: 242245.

Usha Rani, P., Veeraiah, K. and Sridhar, S. 2002. Studies on integrated nutrient management in chillies. In: Proceeding of Intentional Conference of Vegetable, Bangalore, 11-14 November, pp 174.

Yadav, R.H. and Vijayakumari, B. 2004. Impact of vermi-compost on biochemical characters of chilli (Capsicum annuum L.). J. Eco-toxicol. Environ. Monitoring, 14: 51-56.

\section{How to cite this article:}

Anupam Pariari and Suddhasuchi Das. 2017. Response of Chilli (Capsicum annuum L.) to Different Sources and Combination of Nitrogen. Int.J.Curr.Microbiol.App.Sci. 6(4): 972-976. doi: https://doi.org/10.20546/ijcmas.2017.604.122 